\title{
Changing forest values, forest legislation and management in Canada ${ }^{1}$
}

\author{
by Pauline Myre $^{2}$
}

\section{Introduction}

This paper will describe Canada's forests and the changing public values influencing forest legislation and forest management in Canada over the last century.

Forests are a dominant feature of Canada's landscape, covering close to $50 \%$ of the country ( 417 million hectares). These vast forest resources have been integral to the development of Canada as a nation and to our culture, traditions and history. In Canada, most of the forests are publicly owned. Harvesting on provincial Crown lands is done almost exclusively by private forest companies under lease agreements with individual provinces. These agreements grant companies the right to cut timber, but provide no rights to the forests' land, water, and wildlife resources. Most of the long-term leases now require the companies to regenerate the forest land, build roads, as well as protect the forest area from fire and pests.

Forest legislation and management in Canada have evolved through six stages over the last century. Changes in public values and attitudes have influenced these changes. Moreover, a more competitive environment, the need for increased efficiency and shrinking budgets have changed the role of governments. Canada has responded to the growing public concern regarding forests by introducing legislation, policies and programs to protect and sustain the timber and non-timber values of Canada's forests.

Forests are a major component of the Canadian identity. They characterize our landscape, and enrich the lives of every Canadian. Forests are critical elements in Canada's future development as a society and as a nation.

Few countries rely more heavily on their forest resources for their economic livelihood. Forest industries contribute substantially to every province and territory. Approximately 840000 Canadians work directly or indirectly for forest industries or for companies that support them. Almost 340 communities depend on the forest for more than $50 \%$ of their economic base. Hundreds of Aboriginal communities also rely on forests. In 1996, forest industries in Canada produced close to $\$ 60$ billion worth of forest products. In 1996, those same forest industries contributed $\$ 32.1$ billion to Canada's balance of trade.

Canada's forests also provide many other benefits. They clean our air and our water and provide habitat for more than 140000 wildlife species. Forests are also a backdrop to a multibillion dollar tourism industry. With such a mosaic of products and values, Canada's forests represent a substantial management challenge.

\footnotetext{
${ }^{1}$ Paper presented at the Forest Management Into The Next Century - What will make it work? conference, 19 November 1997, Spokane, Washington. This paper is based largely on a theme chapter from The State of Canada's Forests 1996-1997 and a recent address by Dr. Yvan Hardy, Assistant Deputy Minister, C anadian Forest Service, Natural Resources Canada when he was awarded an honorary doctorate at the University de Gembloux in Belgium. ${ }^{2}$ Canadian Forest Service, Natural Resources Canada, 580 Booth Street, Ottawa, Ontario, Canada K1A 0E4.
}

The majority of Canada's forests share a common feature: they are publicly owned. The provinces and territories manage $71 \%$ of Canada's forests. The federal government is responsible for $23 \%$ of forest lands, mostly in the north. A further $6 \%$ of Canada's forest are privately owned by more than 450000 woodlot owners. The proportion of private land is much higher in Atlantic Canada than in other regions. Quebec has the most privately owned forest land, from which approximately $20 \%$ of the province's harvest is taken. However, the annual volume of private timber harvested in $\mathrm{BC}$ is considerably larger than in any other province.

Slightly more than $50 \%$ of Canada's forest land -244 million ha - is designated as commercial or "timber productive" forest land. The provinces own close to $90 \%$ of this timber productive land. (A productive forest is defined as capable of producing trees of commercial species in a reasonable length of time.) Of this productive forest, only about half is accessed and under some kind of management regime. This varies considerably from one province to the other depending on such things as quality of timber, road networks, terrain and distance to mills. Less than one half of $1 \%$ of Canada's commercial forests are harvested each year.

An estimated $7.6 \%$ of Canada's forests are protected by legislation. In addition, approximately $5 \%$ of our forests are protected from harvesting by provincial policy because these forests are on steep slopes or along waterways. It is also important to note that approximately $38 \%$ of Canada's forests are considered open forests, where no commercial harvesting takes place because the trees are either too small or not of commercial value. This mostly northern forest land is made up of shrubs, marshes and muskegs.

Harvesting rights for timber are given to private companies through a variety of timber leases. The agreements grant the companies the right to cut timber, but provide no rights to the forest land, water, wildlife or other resources. Although there are a few dozen distinct types of forest leases used in Canada, with differences from one province to another, they can be grouped into three classes: long term leases of land area, medium term leases based on a volume allotment of timber, and short term agreements to harvest small amounts of timber.

The long term leases providing exclusive cutting rights are generally available only to companies with manufacturing facilities that require large volumes of wood annually. The leases are for 20 to 25 years and can be renewed indefinitely provided the companies satisfy the terms of the agreement. More and more conditions are now part of these long term area-based leases; companies must regenerate and tend the area harvested, protect it from fire and pests, and build roads. In addition, companies must now protect wildlife and habitat, and take into account other values such as Aboriginal hunting grounds or burial sites.

Medium term volume licenses usually last for 15 to 20 years and have less conditions attached to them. Short term agreements are usually given to operate Christmas tree operations 
or for harvesting fuel wood. Usually there are no management responsibilities attached to these short term quota-based or auction-based agreements.

\section{Historical Overview of Forest Legislation and Management}

To understand how forests are managed in Canada today, it is important to review how those forests were managed over past centuries. Forest policy and legislation in Canada has evolved through six stages.

\section{Unregulated Exploitation}

It did not take long for the first settlers in North America to recognize the value of forests for commercial timber. The first policy for North America was that of the British government, intended to preserve large timber — mainly white pine — for masts for the Royal Navy. Timber was marked by agents of the Crown with the broad arrow or crowfoot, the mark of the British government property reserving the timber for masts. Around the mid-17th century there was a shortage of suitable timber in Europe and many conflicts between Britain and other nations cut off established sources of supplies. Stories of limitless stands of timber in the New World generated great interest and helped to speed the immigration of settlers to North America.

The pioneers initially saw forests as a barrier to their settlement, but they quickly began to recognize the value of the forests for commercial lumber to build houses. As the mast trade was being established, the sawmill industry was growing fast.

The timber trade to Britain was well established by the early 1800 s, and the settlers were busy building communities and penetrating further westward. There was little concern over the future of the forests as there was always wood further inland or upriver.

\section{Regulation for Revenue (Mid- to Late 19th Century)}

As the timber trade expanded, Upper and Lower Canada began to recognize it as a potential source of revenue. In 1826, regulations provided for the payment of timber dues on wood cut on Crown lands, specified minimum diameters of trees for cutting and permitted anyone to harvest Crown wood upon payment of a fixed scale of rates. Before this, only Royal Navy contractors or their licensees could harvest Crown timber. It was this kind of legislation, which provided a secure and potentially bountiful source of revenue, that had such a strong influence on the drafting of the British North America Act of 1867; it provided an important basis for provincial control over resources and the retention of revenues from Crown lands.

By the mid- 1800 s, the lumber trade was a booming and profitable business, and competition to enter it was fierce. To bring a degree of organization to the development of Crown forests, the government of the United Provinces passed regulations in 1846 for the granting of licenses. This action spread quickly to the other provinces. Despite increasing regulation of the timber trade, there were few limits on harvesting. The new legislation did not recognize or deal with the problems of settlement and exploitation. Then, on July 1, 1867, the Dominion of Canada was established by confederation of the British North American provinces.

\section{Conservation (Late 19th to Mid-20th Century)}

In the late 19th century, the voices of concern over the state of the forests began to grow in numbers and influence. The American Forestry Association was formed in 1875. A number of influential Canadians were persuaded to join, and in 1882 , the American Forestry Congress was held in Montreal. The theme of the conference was the need to manage and conserve forest resources. Although the only immediate action taken was appointment of a federal forestry commissioner, it was becoming clear that forests required protection — particularly from fires - and that government action was needed to ensure the adequate regeneration of forests.

The rapidly developing pulp and paper industry influenced many of the changes in forest policy at this time. Its largescale and capital-intensive nature, combined with its need for large amounts of raw material, required a different approach from the kind of support developed for the smaller-scale lumber industry.

The conservation era also saw the establishment of the Canadian Forestry Association in 1900, largely to promote forest conservation and propagation. Federal regulations promoted forest conservation, and the first National Forestry Convention, held in Ottawa in 1906, became an expression of awareness on the part of government, the forest industry and the public regarding the importance of forests and the need for their care and protection.

The first provincial forest service was established in Quebec in 1909. In the same year, the federal government passed the Act to Establish a Commission for the Conservation of Natural Resources. Although short-lived, the Commission became a major research institution. The inventory it initiated in Nova Scotia in 1909 and 1910 became the first forest inventory of an entire province.

The Forest Products Laboratories of Canada were established in Montreal in 1913, to develop wood products suitable for aeroplane construction (research and development would later become one of the most significant federal roles in forestry). The age of scientific forestry had begun, and despite the intervention of the war, forest protection measures were in place, forestry practices were regulated, and detaied inventories were carried out.

Timber Management (Mid-20th Century to Late 1980s)

The next era witnessed some momentous historical events throughout the world. Technological and cultural changes were occurring at a frenetic pace, and forestry was swept along in the current.

In the $1930 \mathrm{~s}$, data collected in forest inventories made it clear that forest resources had been depleted under the traditional system of licensing, threatening the viability of the industry and the stability of communities dependent on forestry. Several provinces responded by appointing Royal Commissions to look into the matter. The Commissions recommended adopting sustained-yield policies (i.e., managing for the continuous production of timber to achieve a balance between net growth and harvest) and amending the tenure system.

A licensing system also was required for Crown lands that would provide sufficient incentive for industry to practice sustained-yield forestry while ensuring that governments received adequate royalties.

New Brunswick was the first province to impose specific management responsibilities, requiring licensees to submit 
management plans with their applications for cutting permits. By the 1960 s, most provinces had adopted an incentivebased tenure system in which long-term rights to Crown land were granted in exchange for a commitment to practice sustained-yield forestry. Licensees were required to submit and follow area-based management plans. Tenure reform continued and over time more and more management responsibilities were shifted from the provincial forestry services to forest industry licensees. The policy model of granting extensive area-based licenses in return for forest management planning and silviculture remains largely in place today.

The forest management era also saw the development of legislation governing the forestry profession in several provinces. The codes of ethics and standards of practice adhered to by members of the professional associations play an important role in responsible forest management.

The roles of federal, provincial and territorial governments underwent significant changes during this era. In 1930 (during the Great Depression), the federal government returned jurisdiction over natural resources, including forests, to the three prairie provinces. Until then, control over these lands had provided the federal government with significant influence over forest management. After these Natural Resource Transfer Agreements, however, control over forests by a depleted federal forest service was restricted to the northern forests and to a small percentage of federal lands in the provinces (e.g., Indian reserves, national parks and military bases). During World War II, the federal government assumed control over the production and pricing of forest products, and after the war, it sought to encourage forest management and expansion of the industry indirectly - through the use of its spending power.

The Canada Forestry Act of 1949 enabled the federal government to enter into cost-shared conditional-grant programs with the provinces. The federal Department of Forestry, created in 1960 to strengthen the federal role, lasted only until 1966. The emphasis then shifted to cost-shared regional development programs, initially focussing on access road construction and mill modernization. In 1971 federal efforts began to focus on forest management and regeneration, a focus reflected in subsequent federal-provincial agreements that lasted until the mid-1990s.

By 1981, several forestry initiatives launched by the federal government resulted in a discussion paper entitled "A Forest Sector Strategy for Canada." This, together with the 1987 National Forest Sector Strategy, outlined the federal role in areas within its jurisdiction (e.g., trade enhancement, public education, and forestry research and development). This focus was clear in 1986, when the federal government divested itself of forest-related administration in the Northwest Territories, transferring responsibility for forest management to the territorial government. A similar process is underway in the Yukon Territory and should be complete in 1998.

Until the 1970s, most forestry in Canada was focussed on the harvesting of mature stands, with little emphasis on regeneration and silviculture. But the National Forest Regeneration Conference held in Quebec City in 1977 brought to the forefront the problems related to forest renewal, including the back$\log$ of cut-over areas that were not adequately regenerated. Subsequent conferences emphasized the need to adopt new forest management techniques. These efforts spurred a greater focus on the application of intensive forest management, which began to consider forest values other than timber.

Hand in hand with rising public awareness came growing challenges to the status quo and increasing restrictions on the forest industry. The sustained-yield framework of forestry was clearly inadequate to deal with the range of demands being placed on Canada's forests. The 1980 s brought the first attempts to broaden the scope of forest management to take into account multiple forest uses and functions.

Sustainable Forest Management (Late 1980s - ongoing)

Against the backdrop of a rising world population, unacceptable worldwide poverty levels, environmental degradation, forest depletion and deforestation, the deterioration of the ozone layer, and fears over global warming, the United Nations Brundtland Commission report, Our Common Future, was released in 1987. That report alerted the world to the mounting problems and proposed the concept of "sustainable development." Canada was one of the first countries to embrace the concept and is a world leader in applying it to forestry. This new approach has resulted in a shift of forest policy, with ecosystem sustainability becoming a major focus of forest management across the country.

The federal government took the lead in promoting sustainable forestry in 1989 by passing the Canada Forestry Act, which established for the second time — but briefly — a fullfledged federal Department of Forestry (now called the Canadian Forest Service within Natural Resources Canada). The new Act explicitly required the Minister of Forestry to promote sustainable development, which also became the cornerstone of the 1992 National Forest Strategy. This Strategy, endorsed by the provinces and territories as well as many other forest stakeholders, recognized the need to manage and sustain entire forest ecosystems, not only the timber resource. Efforts are now underway to renew this strategy.

From the early 1990 s, provincial forest policies have increasingly recognized ecological and social considerations. Many provinces have now established legislation based on the principles of sustainability. The federal role in forestry also evolved and now focusses on the delivery of science and technology programs within a national policy framework. Through national science networks, the federal government focusses on developing the knowledge of forest ecosystems and management practices to sustain forests.

While federal and provincial governments were amending their policies and legislation, forest industries and other private organizations developed their own codes of forest practices based on the principles of sustainable forest management. These initiatives aim to assure the public, governments and consumers of forest products that good forest practices are being followed. They are also a response to requests by public interest groups for predictability and transparency in the forest management decision-making process.

Along similar lines, many forest industries and private landowners who depend on export markets are embracing the concept of forest certification - a system whereby an independent organization certifies products that originate from sustainably managed forests. Two major systems are being implemented in Canada. The first, developed under the auspices of the Canadian Standards Association (CSA), is consistent with the Environmental Management System of the International Organization for Standardization (ISO). The 
second is that of the Forest Stewardship Council, an international organization founded to promote environmentally appropriate, socially beneficial and economically viable management of the world's forests. The trend toward certification aims to provide consumers at home and abroad with assurances that forests are being managed responsibly.

\section{Public views and values}

Also important in this era is the increased degree of public participation in forest management. Until recently, public pressure had little influence over the evolution of forest legislation. Today, concerns about the environment and human health, and more knowledge about resource issues, have led the public to insist on a greater role in decision-making regarding forest management practices. In response, provinces have developed public consultation processes at the planning stage of forest operations to enable interested citizens to share their views with the people working directly with the resource.

Now, forest managers must consider a much broader set of values, including the ecological and biological diversity of flora and fauna, as well as recreation and spiritual values. As part of Canada's commitment to sustainable development, a framework of criteria and indicators of sustainable forest management has been developed by the Canadian Council of Forest Ministers. A first report outlining Canada's capacity to report on forest sustainability was published in the fall of 1997. Management approaches, and the tools needed to collect data and measure those values, are being developed.

\section{Aboriginal and private land concerns}

Aboriginal efforts to secure lands, manage the forest resources on reserves, and obtain rights to other forest resources are meeting with some success. Respect for Aboriginal rights is a key component of current international initiatives, and the federal government is committed to promoting Aboriginal involvement in forestry and to recognizing Aboriginal and treaty rights. Several provinces are also developing new approaches in this area. Traditional Aboriginal ecological knowledge is now being recognized as an important component of sustainable forest management.

There also is a growing recognition of the role of private woodlots in timber supply, economic development and environmental benefits. In some provinces, notably Quebec, this is resulting in a trend toward the regulation of private forests at the municipal level. Although most private woodlots are located east of Manitoba, organizations representing private woodlot owners now exist in all provinces. Such organizations can play an important part in the development of forest policy. In New Brunswick, for example, woodlot owner organizations played an important role in one of the six field trials designed to test the CSA certification standard that took place in early 1996.

\section{New knowledge and new partners}

The present era of sustainable forest management is also rooted in science - in a greater understanding of the components of forest ecology and its interrelationships with the global ecology. This understanding is enabling scientists to assess Canada's progress toward the sustainability of forest ecosystems. As these concerns are incorporated into present-day for- est legislation, there are direct impacts on how forest management is implemented in Canada, from landscape management, to alternative harvesting methods.

Canada has developed various tools and processes to test and measure sustainable forest practices. For example, a network of model forests has been created to enable various stakeholders to work together to test and apply ecosystem management. Some provinces are also experimenting with community forests whereby the local residents are responsible for planning and managing the local forest for various values.

In addition, governments and many other organizations are restructuring to accommodate the new requirements of sustainable development with reduced budgets. The Canadian Forest Service (CFS), for example, has reorganized its research program into science networks that are based on major areas of research. It will carry out research projects in partnership with universities and other centres of expertise. The CFS will also place greater reliance on its existing initiatives (e.g., the Model Forest Network) for field experimentation and the transfer of technologies. Provincial governments and other organizations are undertaking similar exercises to make better use of limited resources.

\section{Global Stewardship (1992 - ongoing)}

Forests have moved onto the international stage. As a country that accounts for $10 \%$ of the world's forests and almost $20 \%$ of global trade, Canada's forest agenda is fundamentally connected to global economic and environmental systems. As a result, we are playing a key role in on-going international discussions on forests. In addition to the national framework of criteria and indicators, in 1995 Canada endorsed a common set of criteria and indicators of sustainable forest management for temperate and boreal forests outside Europe (known as the "Montreal Process").

International trade has always played a key role in shaping Canadian forest policy. Markets are now more global, large trading blocks and new competitors are emerging. As the world's largest exporter of forests products, the public beyond our borders is getting quite vocal and influencing changes in forest policies in Canada. International pressure has had a profound effect on our domestic policies as evidenced by the many changes (mentioned earlier) in provincial forest policies over the past decade. Activities range from implementing new management practices in public forests, to supporting forest management on private lands, protecting valued landscapes and conserving biodiversity.

Canada is also pushing for an international forest convention that would provide common rules for managing forests while recognizing the different values and forests of the world's forest nations. A global commitment and a set of common rules are key ingredients to sustainability. Although many forest nations have demonstrated a willingness to pursue sustainability, it is difficult to get agreement on a common set of rules, mainly because forest types and values vary greatly between forest nations. For example, developing countries consume most of their wood as fuel. In Canada, the sheer size of our forests precludes management on the intensive, small-scale basis practiced in most of Europe. The challenge, therefore, is to determine what elements are common to all types of forests and what factors are unique to individual countries, regions and communities. In short, we need to 
define and measure sustainability, and that is where criteria and indicators can play an essential role. Science-based knowledge, tools and methodologies will help us measure our progress.

\section{Conclusion and Summary}

It has been only 130 years since Confederation. In this brief span of time, forestry in Canada has undergone changes that are as far-reaching as those experienced by society at large. In fact, the pace of change is increasing. We have gone from being hewers of wood in a colonial outpost to becoming one of the most advanced nations in forest management. Today, Canada leads the way in advancing the promise of sustainability, and we serve as a worldwide model in the practical application of sustainable forest management. With our forests valued for much more than just timber, we have amended our forest legislation and policies accordingly, we have developed codes of practice, we are learning to manage forests as ecosystems, we are involving the public in decision-making, and our science is developing decision-support systems for forest managers.

We are still struggling with difficult issues such as land use pressures, including protected areas and Aboriginal land claims, but we are clearly embarked on the road to sustainability, working in partnership, developing networks and sharing our knowledge on forests. 